\title{
BMJ Open Relationship between wealth and emotional well-being before, during, versus after a nationwide disease outbreak: a large-scale investigation of disparities in psychological vulnerability across COVID-19 pandemic phases in China
}

\author{
Haiyang Yang (D) , ${ }^{1}$ Jingjing $\mathrm{Ma}$ (D) ${ }^{2}$
}

To cite: Yang $\mathrm{H}, \mathrm{Ma} \mathrm{J}$. Relationship between wealth and emotional well-being before, during, versus after a nationwide disease outbreak: a large-scale investigation of disparities in psychological vulnerability across COVID-19 pandemic phases in China. BMJ Open 2021;11:e044262. doi:10.1136/ bmjopen-2020-044262

- Prepublication history for this paper is available online. To view these files, please visit the journal online (http://dx.doi org/10.1136/bmjopen-2020044262).

Received 30 August 2020 Accepted 13 May 2021

D) Check for updates

(c) Author(s) (or their employer(s)) 2021. Re-use permitted under CC BY-NC. No commercial re-use. See rights and permissions. Published by BMJ.

1Johns Hopkins University, Baltimore, Maryland, USA ${ }^{2}$ Peking University, Beijing, China

Correspondence to Dr Jingjing Ma; jingjingma@nsd.pku.edu.cn

\begin{abstract}
Objectives This research investigated whether certain population segments might be more psychologically vulnerable in different phases of a pandemic. Specifically, the research examined how disparities in wealth might be associated with differences in emotional well-being before, during, versus after the nationwide COVID-19 outbreak in China.
\end{abstract}

Setting, participants and outcome measures In this large-scale cross-sectional study, three rounds of nationally representative data collection ( $\mathrm{N}=27 \mathrm{760})$ were conducted immediately before (December 2019), in the midst of (February 2020), versus immediately after (April 2020) the countrywide COVID-19 outbreak in China. Participants' emotional well-being, wealth (income, property ownership) and demographic information were measured using established instruments. Statistical analyses examined relationships between disparities in different types of wealth and emotional well-being across the pandemic phases.

Results Although the onset of the coronavirus outbreak substantially degraded emotional well-being, having a higher income was associated with better emotional wellbeing during the outbreak. Property owners experienced a larger drop in emotional well-being during the outbreak than non-owners; however, the former was not emotionally worse off than the latter during the outbreak. After the nationwide COVID-19 outbreak had been contained and the economy reopened, those with more wealth of either type again became better off in emotional well-being than those with less. The highest income segment even experienced better emotional well-being after the end of the nationwide outbreak than prior to the outbreak. In contrast, the lowest income segment became worse off in emotional well-being after the nationwide outbreak ended than before the outbreak began.

Conclusion People with less wealth tend to be emotionally worse off throughout the different phases of a disease outbreak. In particular, even after an outbreak has been contained, the poor are less able to restore their
Strengths and limitations of this study

This research used large-scale nationally representative datasets to examine the psychological impacts of a contagious disease outbreak.

- The relationship between wealth and emotional well-being was investigated across pandemic phases-before, during, versus after the nationwide COVID-19 outbreak in China.

- Overall emotional well-being, positive emotion and negative emotion indexes were each analysed to dissect the psychological patterns.

- This research focused on individuals residing in China, and hence the extent to which the findings are generalisable to residents of other countries requires further investigation.

- The longer-term (eg, after the complete eradication of COVID-19) psychological implications of experiencing a nationwide disease outbreak require further research.

psychological well-being. Policies and interventions are needed to address disparities in mental health in the age of pandemics.

\section{INTRODUCTION}

In recent decades, people around the world have been impacted by many major disease outbreaks including COVID-19, Ebola, H1N1 (Hemagglutinin Type 1 and Neuraminidase Type 1), SARS (Severe Acute Respiratory Syndrome), MERS (Middle East Respiratory Syndrome) and Zika. Due to the ever growing exploitation of the natural environment and increasing global travel and commerce, pandemics are anticipated to occur at an accelerated pace. ${ }^{1-3}$ One of the societal-level 
consequences of pandemics is the degradation of people's emotional well-being. ${ }^{4}$ However, relatively little is known about the extent to which people may be psychological vulnerable to the different phases of a pandemic. Even less is known about which population segments might be less able to maintain their psychological well-being across disease outbreak phases. The current research seeks to help fill these gaps in the literature by investigating how disparities in wealth may be associated with disparities in emotional well-being before, during, versus after the nationwide COVID-19 outbreak in China.

Prior research shows that wealth can influence emotional well-being in non-pandemic contexts, ${ }^{5-7}$ and that wealth can influence physical health and objective well-being during a pandemic. ${ }^{8}$ We complement this research stream by examining the relationship between wealth and emotional-welling across pandemic phases, and by investigating the psychological implications of disparities in income and property ownership. These two types of wealth have been established, respectively, as an indirect and direct indicator of wealth. ${ }^{10}$ More importantly, the two types of wealth differ in convertibility: Income can be converted into other types of resources relatively quickly, whereas property ownership cannot be converted into other types of resources as easily and quickly. Hence, examining the two wealth types can inform the understanding of how disparities in wealth may influence psychological well-being.

\section{METHODS}

Our datasets came from three large-scale nationally representative, cross-sectional surveys conducted before, during, versus after the countrywide COVID-19 outbreak in China. An identical sampling method was used in all three data collection rounds. The first was carried out immediately before coronavirus infections were publicly reported in China (late December 2019; N=11 131; 48\% women; $66 \%$ married; average age of 37.78 ; residing in 32 provincial regions). The second was conducted during the peak of the pandemic in China (mid-February, 2020; $\mathrm{N}=3000 ; 50 \%$ women; $69 \%$ married; average age of 34.7; residing in 30 provincial regions). The third was conducted immediately after the nationwide outbreak had been contained and the economy reopened in China (early April, 2020; N=13629; 49\% women; 60\% married; average age of 37.47 ; residing in 32 provincial regions). In each survey, participants were asked to respond to an established scale of emotional well-being. ${ }^{6}$ Specifically, they indicated whether or not they experienced different positive (ie, smile/laughter, enjoyment, happiness) and negative emotions (ie, anger, sadness, stress, worry) yesterday $(1=$ experienced, $0=$ did not $)$. Participants also completed two measures pertaining to their wealthmonthly household income (in Renminbi (RMB)) and real estate ownership ( $1=$ own a property, $0=$ do not own). For demographic variables, participants indicated their age, sex ( $1=$ female, $0=$ male), marital status $(1=$ married, $0=$ not married) and residence region.

To analyse the data, we conducted $\chi^{2}$ tests on whether the percentage of individuals experiencing each of the emotions differed across the three pandemic phases. We also conducted a series of regressions to investigate the relationship between wealth and emotional well-being across the phases. Specifically, we constructed an index of positive emotions (with a value range of $0-1$ ) by taking the average of the positive emotion measures, as well as an index of negative emotions (with a value range of $0-1$ ) by averaging the negative emotion measures. Following an established approach, ${ }^{11}$ we also constructed an index of overall emotional well-being by subtracting the negative emotion index from the positive emotion index. This overall index (with a value range of $0-1$ ) thus accounted for experiences of both positive and negative emotions. These three indexes served as the dependent variables in our analyses. Also, following a prior approach, ${ }^{4}$ we normalised the household income measure and linearly transformed the value by dividing it by 10000 so that the monthly income is measured in units of RMB10 000 . Finally, we coded whether participants were residing in Hubei $(1=y e s, 0=$ no), the province where the first Chinese cases of COVID-19 were reported. ${ }^{12}$

We created two time-period dummy variables representing the 'during the outbreak' and 'after the outbreak' periods, respectively. Hence, the period before the outbreak was represented by zero values on the two dummies, and this period served as the baseline against which the other two periods were compared. We conducted three sets of regression analyses using different dependent variables: overall emotional well-being index, positive emotion index and negative emotion index. In each set of analyses, the two time period dummies, income and real estate ownership, as well as the interaction terms between the two dummies and the wealth measures were the predictors of interests. The demographic variables-residing in Hubei, age, sex and marital status-were included as control variables. The series of models we ran helped assess the robustness of the significant coefficient estimates.

\section{RESULTS}

\section{Distribution of emotions}

A series of $\chi^{2}$ analyses showed that, with the exception of anger, all other emotions differed significantly across the three pandemic phases (see tables 1 and 2 for distributions): as compared with before or after the nationwide outbreak, fewer individuals experienced positive emotions during the outbreak. Conversely, more individuals experienced negative emotions during the outbreak than before or after it.

\section{Emotional well-being \\ Pandemic phases}

As shown in tables 3-5, we ran three sets of regression analyses with the overall emotional well-being index, 
Table 1 Distribution of each emotion before, during, versus after the nationwide COVID-19 outbreak in China

\begin{tabular}{llllll}
\hline & $\begin{array}{l}\text { Before, } \\
\%\end{array}$ & $\begin{array}{l}\text { During, } \\
\%\end{array}$ & After, $\%$ & $\chi^{2}$ & P value \\
\hline Enjoyment & 79.13 & 60.30 & 77.59 & 485.3743 & $<0.0001$ \\
Happiness & 77.34 & 61.33 & 76.83 & 355.4037 & $<0.0001$ \\
Laughter & 69.09 & 50.83 & 67.35 & 365.5754 & $<0.0001$ \\
Anger & 30.73 & 31.90 & 31.50 & 2.3576 & 0.3076 \\
Sadness & 25.54 & 43.47 & 28.39 & 372.4647 & $<0.0001$ \\
Stress & 41.81 & 59.70 & 49.08 & 335.4379 & $<0.0001$ \\
Worry & 27.86 & 49.13 & 32.85 & 488.5911 & $<0.0001$ \\
\hline $\mathrm{N}$ & 11131 & 3000 & 12513 & & \\
\hline
\end{tabular}

The percentage of people experiencing each emotion during each pandemic phase is shown. $\mathrm{N}$ represents the respective final sample size.

positive emotion index, and negative emotion index as the dependent variable, respectively. The duringoutbreak dummy exhibited a significant effect on overall emotional well-being across all models, indicating that people's psychological well-being substantially worsened when the nationwide coronavirus outbreak began. Further, this dummy also exhibited a consistent significant effect on the positive emotion index as well as on the negative emotion index. That is, people experienced fewer positive emotions and more negative emotions during nationwide coronavirus outbreak than prior to the outbreak.

The after-outbreak dummy exhibited a consistent significant effect on overall emotional well-being,

Table 2 Distribution of the number of positive/negative emotions experienced before, during, versus after the nationwide COVID-19 outbreak in China

\begin{tabular}{|c|c|c|c|}
\hline & Before & During & After \\
\hline \multicolumn{4}{|c|}{ No of positive emotions } \\
\hline 0 & $11.55 \%$ & $28.90 \%$ & $13.13 \%$ \\
\hline 1 & $10.23 \%$ & $11.13 \%$ & $9.67 \%$ \\
\hline 2 & $19.32 \%$ & $18.57 \%$ & $19.49 \%$ \\
\hline \multirow[t]{2}{*}{3} & $58.90 \%$ & $41.40 \%$ & $57.71 \%$ \\
\hline & \multicolumn{3}{|c|}{$\chi^{2}=490.8384, p<0.0001$} \\
\hline \multicolumn{4}{|c|}{ No of negative emotions } \\
\hline 0 & $39.57 \%$ & $26.40 \%$ & $35.36 \%$ \\
\hline 1 & $22.24 \%$ & $18.23 \%$ & $21.66 \%$ \\
\hline 2 & $19.24 \%$ & $18.27 \%$ & $19.08 \%$ \\
\hline 3 & $10.61 \%$ & $18.97 \%$ & $13.61 \%$ \\
\hline \multirow[t]{2}{*}{4} & $8.35 \%$ & $18.13 \%$ & $10.29 \%$ \\
\hline & \multicolumn{3}{|c|}{$\chi^{2}=662.3433, p<0.0001$} \\
\hline $\mathrm{N}$ & 11131 & 3000 & 12513 \\
\hline
\end{tabular}

The percentage of people experiencing the respective number of positive/negative emotions during each pandemic phase is shown. indicating that even after the nationwide outbreak had been contained and the economy reopened, people's emotional well-being, on average, did not fully recover to the levels before the outbreak. This dummy exhibited a significant effect on the positive emotion index in models $1-3$ but not in models $4-7$. However, the dummy exhibited a consistent significant effect on the negative emotion index, indicating that even after the nationwide outbreak had been contained, people, on average, still experienced more negative emotions than before the outbreak.

\section{Wealth}

Both types of wealth had consistent significant effects on overall emotional well-being. That is, disparities in wealth were associated with disparities in emotional well-beinghaving a higher income or owning (vs not owning) real estate was associated with a higher level of emotional wellbeing. Analyses using the positive and negative emotion indexes showed that having more of either type of wealth was associated with experiences of more positive emotions and fewer negative ones.

\section{Wealth $\times$ pandemic phase interactions}

Income level did not interact with the during-outbreak dummy to impact overall emotional well-being. In other words, the nationwide outbreak led to a parallel drop of emotional well-being across high versus low income groups (figure 1). In analyses using the positive emotion index, this interaction was also not significant. In analyses using the negative emotion index, the interaction between income level and the during-outbreak dummy approached significance, indicating that higher income individuals experienced a larger increase in negative emotions when the pandemic began. However, as the analyses using the overall emotional well-being index suggest, at the aggregate level, the income $\times$ duringoutbreak interaction was not significant.

A consistent significant real estate ownership $\times$ duringoutbreak interaction effect on overall emotional wellbeing was found (figure 2). We conducted a series of contrasts to further dissect this interaction: Although real estate owners experienced significantly better emotional well-being than non-owners before the outbreak $\left(\mathrm{M}_{\text {owner }}=0.47, \mathrm{SE}_{\text {owner }}=0.01\right.$ vs $\mathrm{M}_{\text {non-owner }}=0.25, \mathrm{SE}_{\text {non-owner }}=0.01$; $\mathrm{F}(1,26638)=203.18, \quad \mathrm{p}<0.0001, \mathrm{~d}=0.17)$, the former group was only directionally (not significantly) better in emotional well-being than the latter group during the outbreak $\left(\mathrm{M}_{\text {owner }}=0.12, \mathrm{SE}_{\text {owner }}=0.01\right.$ vs $\mathrm{M}_{\text {non-owner }}=0.07, \mathrm{SE}_{\text {non- }}$ $=0.03 ; \mathrm{F}(1,26638)=2.58, \mathrm{p}=0.11, \mathrm{~d}=0.02)$. In analyses using the positive emotion index, real estate ownership significantly interacted with the during-outbreak dummy, indicating that, after the start of the pandemic, real estate owners experienced a larger decrease in positive emotions than non-owners. In analyses using the negative emotion index, real estate ownership also significantly interacted with the during-outbreak dummy, indicating that, after the start of the pandemic, real estate owners 
Table 3 The relationship between wealth and emotional well-being before, during, versus after the nationwide COVID-19 outbreak in China

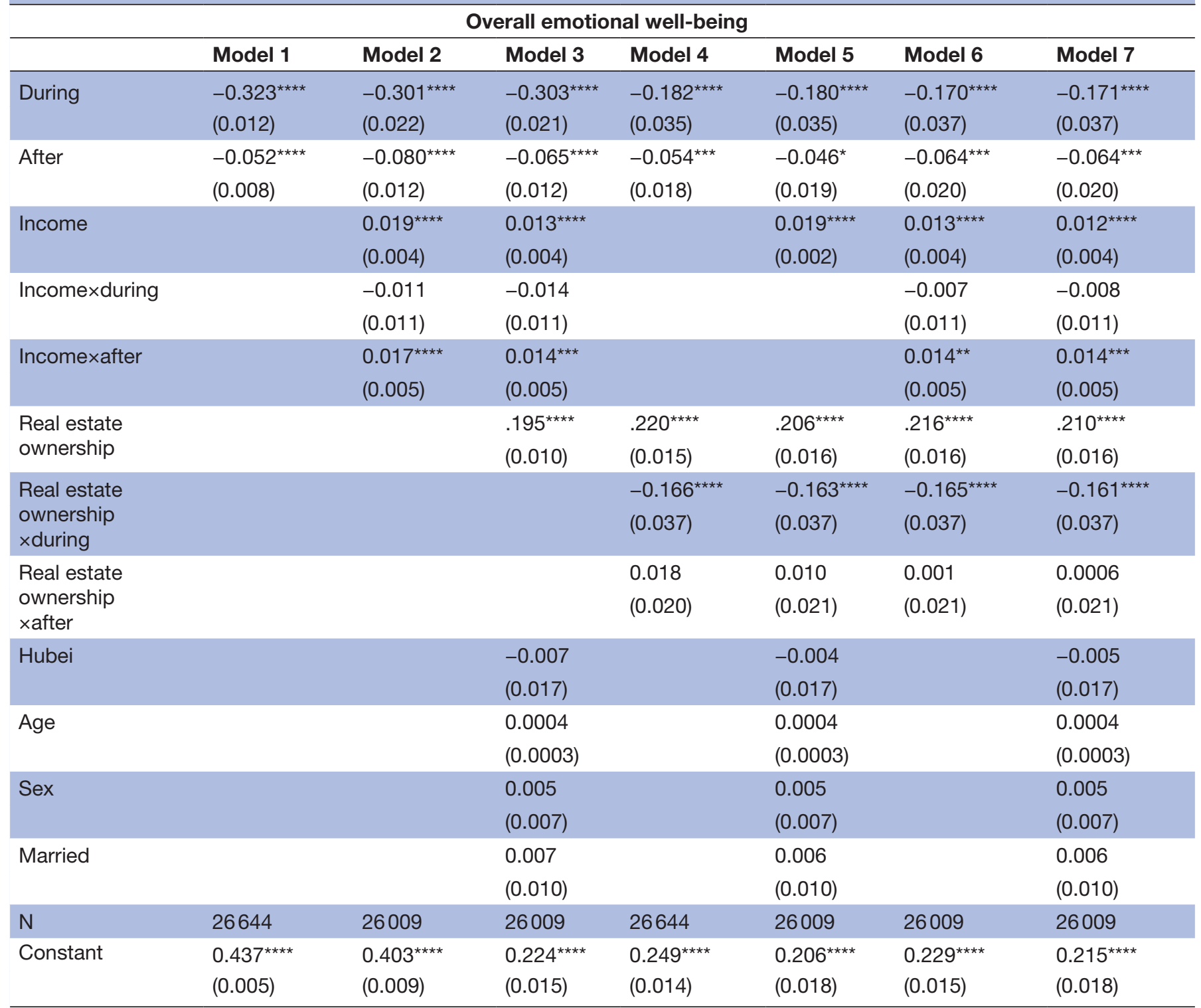

SEs are shown in parentheses below coefficient estimates. Dummy variable coding: during (1=during the nationwide COVID-19 outbreak, $0=$ other time period), after ( $1=$ after the nationwide COVID-19 outbreak had been contained and the economy reopened, $0=$ other time period), real estate ownership ( $1=$ owner, $0=$ non-owner), Hubei ( $1=$ in Hubei, $0=$ not in Hubei), sex $(1=$ female, $0=$ male) and married $(1=$ married, $0=$ not married). (Zero values on the during and after dummies represent the before pandemic time period, which serves as the reference group in the analyses.) $\mathrm{N}$ represents the final sample size of the respective analysis.

${ }^{\star} \mathrm{P}<0.05,{ }^{\star *} \mathrm{p}<0.01,{ }^{* \star *} \mathrm{p}<0.005,{ }^{\star \star \star *} \mathrm{p}<0.001$

experienced a larger increase in negative emotions than non-owners. That is, the patterns of changes in the overall emotional well-being, positive and negative emotion indexes were consistent-despite experiencing a steeper drop in emotional well-being, real estate owners were still not worse off than non-owners.

A consistent significant income $\times$ after-outbreak interaction effect on overall emotional well-being was found, indicating that having a higher income exhibited an even more favourable effect on overall emotional well-being after the end of the nationwide outbreak than before the outbreak began. A Johnson-Neyman analysis (figure 3) was conducted to further dissect this interaction. This analytical technique ${ }^{13}$ has been widely used to determine regions of significance in interaction effects. In the current research context, we used a Johnson-Neyman analysis to estimate the income regions where emotional well-being significantly differed before versus after the pandemic. This analysis showed that the highest income segment experienced even better emotional well-being after the outbreak had been contained than prior to the outbreak. In stark contrast, the lowest income segment experienced significantly lower emotional well-being after the end of the nationwide outbreak than before the outbreak began. 
Table 4 The relationship between wealth and positive emotions before, during, versus after the nationwide COVID-19 outbreak in China

\begin{tabular}{|c|c|c|c|c|c|c|c|}
\hline \multicolumn{8}{|c|}{ Positive emotion index } \\
\hline & Model 1 & Model 2 & Model 3 & Model 4 & Model 5 & Model 6 & Model 7 \\
\hline During & $\begin{array}{l}-0.177^{\star \star \star \star} \\
(0.007)\end{array}$ & $\begin{array}{l}-0.181^{\star \star \star \star} \\
(0.014)\end{array}$ & $\begin{array}{l}-0.187^{\star \star \star *} \\
(0.014)\end{array}$ & $\begin{array}{l}-0.120^{\star \star \star \star} \\
(0.022)\end{array}$ & $\begin{array}{l}-0.115^{\star \star \star \star} \\
(0.022)\end{array}$ & $\begin{array}{l}-0.124^{\star \star \star \star} \\
(0.024)\end{array}$ & $\begin{array}{l}-0.122^{\star \star * *} \\
(0.024)\end{array}$ \\
\hline After & $\begin{array}{l}-0.013^{\star \star} \\
(0.005)\end{array}$ & $\begin{array}{l}-0.023^{\star \star \star} \\
(0.007)\end{array}$ & $\begin{array}{l}-0.018^{*} \\
(0.007)\end{array}$ & $\begin{array}{l}0.003 \\
(0.012)\end{array}$ & $\begin{array}{l}0.004 \\
(0.012)\end{array}$ & $\begin{array}{l}-0.003 \\
(0.013)\end{array}$ & $\begin{array}{l}-0.003 \\
(0.013)\end{array}$ \\
\hline Incomexduring & & $\begin{array}{l}0.004 \\
(0.007)\end{array}$ & $\begin{array}{l}0.002 \\
(0.007)\end{array}$ & & & $\begin{array}{l}0.006 \\
(0.007)\end{array}$ & $\begin{array}{l}0.005 \\
(0.007)\end{array}$ \\
\hline Incomexafter & & $\begin{array}{l}0.005 \dagger \\
(0.003)\end{array}$ & $\begin{array}{l}0.005 \\
(0.003)\end{array}$ & & & $\begin{array}{l}0.005 \\
(0.003)\end{array}$ & $\begin{array}{l}0.005 \dagger \\
(0.003)\end{array}$ \\
\hline $\begin{array}{l}\text { Real estate } \\
\text { ownershipxduring }\end{array}$ & & & & $\begin{array}{l}-0.067^{\star \star *} \\
(0.023)\end{array}$ & $\begin{array}{l}-0.076^{\star \star *} \\
(0.023)\end{array}$ & $\begin{array}{l}-0.071^{\text {** }} \\
(0.023)\end{array}$ & $\begin{array}{l}-0.079^{* * * *} \\
(0.023)\end{array}$ \\
\hline $\begin{array}{l}\text { Real estate } \\
\text { ownershipxafter }\end{array}$ & & & & $\begin{array}{l}-0.014 \\
(0.013)\end{array}$ & $\begin{array}{l}-0.015 \\
(0.013)\end{array}$ & $\begin{array}{l}-0.019 \\
(0.013)\end{array}$ & $\begin{array}{l}-0.018 \\
(0.013)\end{array}$ \\
\hline Hubei & & & $\begin{array}{l}-0.002 \\
(0.010)\end{array}$ & & $\begin{array}{l}-0.001 \\
(0.010)\end{array}$ & & $\begin{array}{l}-0.002 \\
(0.010)\end{array}$ \\
\hline Age & & & $\begin{array}{l}-0.001^{\star \star \star *} \\
(0.0002)\end{array}$ & & $\begin{array}{l}-0.001^{\star \star \star *} \\
(0.0002)\end{array}$ & & $\begin{array}{l}-0.001^{* * * *} \\
(0.0002)\end{array}$ \\
\hline Sex & & & $\begin{array}{l}0.033^{\star \star \star \star} \\
(0.004)\end{array}$ & & $\begin{array}{l}0.033^{\star * * *} \\
(0.004)\end{array}$ & & $\begin{array}{l}0.034^{\star \star \star \star} \\
(0.004)\end{array}$ \\
\hline
\end{tabular}

${ }^{*} \mathrm{P}<0.05,{ }^{* *} \mathrm{p}<0.01,{ }^{* * *} \mathrm{p}<0.005,{ }^{* * * *} \mathrm{p}<0.001$

$+\mathrm{P}<0.10$

Analyses using the positive emotion index showed that, in models 2 and 7, there was a marginally significant income $\times$ after-outbreak interaction-higher income individuals experienced more positive emotions after the end of the nationwide outbreak than before the outbreak began. In analyses using the negative emotion index, a consistent significant interaction was found, suggesting that higher income individuals experienced fewer negative emotions after the end of the nationwide outbreak than before the outbreak began. That is, the differences in overall emotional well-being were largely consistent with the patterns of positive and negative emotions.

Moreover, real estate ownership did not interact with the after-outbreak dummy to impact overall emotional well-being. Analyses using the positive emotion index and negative emotion index also did not yield a significant real estate ownership $\times$ after-outbreak interaction. These patterns suggest that, after the nationwide COVID-19 outbreak had been contained, real estate owners again became better off in emotional well-being than non-owners.

\section{Control variables}

The coefficient estimates for the control variables (residing in Hubei, age, sex and marital status) were not significant in the analyses on overall emotional well-being. However, analyses using the positive emotion index showed that, across the time periods examined in this research, older people, on average, experienced significantly fewer positive emotions, whereas women (vs men) and married (vs not) individuals experienced significantly more positive emotions. Analyses using the negative emotion index 
Table 5 The relationship between wealth and negative emotions before, during, versus after the nationwide COVID-19 outbreak in China

\begin{tabular}{|c|c|c|c|c|c|c|c|}
\hline \multicolumn{8}{|c|}{ Negative emotion index } \\
\hline & Model 1 & Model 2 & Model 3 & Model 4 & Model 5 & Model 6 & Model 7 \\
\hline During & $\begin{array}{l}0.146^{\star \star \star \star} \\
(0.007)\end{array}$ & $\begin{array}{l}0.120^{\star \star \star \star} \\
(0.013)\end{array}$ & $\begin{array}{l}0.117^{\star \star \star \star} \\
(0.012)\end{array}$ & $\begin{array}{l}0.062^{\star \star \star} \\
(0.020)\end{array}$ & $\begin{array}{l}0.065^{\star * \star} \\
(0.020)\end{array}$ & $\begin{array}{l}0.046^{\star *} \\
(0.022)\end{array}$ & $\begin{array}{l}0.049^{\star} \\
(0.022)\end{array}$ \\
\hline After & $\begin{array}{l}0.040^{\star \star \star \star} \\
(0.004)\end{array}$ & $\begin{array}{l}0.057^{\star \star \star \star} \\
(0.007)\end{array}$ & $\begin{array}{l}0.047^{\star \star \star \star} \\
(0.007)\end{array}$ & $\begin{array}{l}0.057^{\star \star \star \star} \\
(0.011)\end{array}$ & $\begin{array}{l}0.050^{\star \star \star \star} \\
(0.011)\end{array}$ & $\begin{array}{l}0.061^{* \star \star \star} \\
(0.012)\end{array}$ & $\begin{array}{l}0.061^{\star \star \star \star} \\
(0.012)\end{array}$ \\
\hline Income & & $\begin{array}{l}-0.009^{\star \star \star \star} \\
(0.002)\end{array}$ & $\begin{array}{l}-0.005^{\star \star} \\
(0.002)\end{array}$ & & $\begin{array}{l}-0.009^{\star \star \star \star} \\
(0.001)\end{array}$ & $\begin{array}{l}-0.005^{*} \\
(0.002)\end{array}$ & $\begin{array}{l}-0.006^{\star \star} \\
(0.002)\end{array}$ \\
\hline Incomexduring & & $\begin{array}{l}0.015^{\star} \\
(0.006)\end{array}$ & $\begin{array}{l}0.016^{\star \star} \\
(0.006)\end{array}$ & & & $\begin{array}{l}0.013^{\star} \\
(0.006)\end{array}$ & $\begin{array}{l}0.013^{\star} \\
(0.006)\end{array}$ \\
\hline Incomexafter & & $\begin{array}{l}-0.012^{\star * \star *} \\
(0.003)\end{array}$ & $\begin{array}{l}-0.009^{* \star *} \\
(0.003)\end{array}$ & & & $\begin{array}{l}-0.009^{* \star \star} \\
(0.003)\end{array}$ & $\begin{array}{l}-0.008^{* \star *} \\
(0.003)\end{array}$ \\
\hline $\begin{array}{l}\text { Real estate } \\
\text { ownership }\end{array}$ & & & $\begin{array}{l}-0.124^{\star \star \star \star} \\
(0.006)\end{array}$ & $\begin{array}{l}-0.139^{\star \star \star \star} \\
(0.009)\end{array}$ & $\begin{array}{l}-0.120^{\star \star \star \star} \\
(0.009)\end{array}$ & $\begin{array}{l}-0.136^{\star \star \star \star} \\
(0.009)\end{array}$ & $\begin{array}{l}-0.122^{\star \star \star \star} \\
(0.009)\end{array}$ \\
\hline $\begin{array}{l}\text { Real estate } \\
\text { ownership } \\
\text { ×during }\end{array}$ & & & & $\begin{array}{l}0.099^{\star * \star *} \\
(0.021)\end{array}$ & $\begin{array}{l}0.087^{* * \star *} \\
(0.021)\end{array}$ & $\begin{array}{l}0.093^{\star \star * \star} \\
(0.022)\end{array}$ & $\begin{array}{l}0.082^{* \star \star *} \\
(0.022)\end{array}$ \\
\hline $\begin{array}{l}\text { Real estate } \\
\text { ownership } \\
\text { xafter }\end{array}$ & & & & $\begin{array}{l}-0.032^{\star \star} \\
(0.012)\end{array}$ & $\begin{array}{l}-0.025^{*} \\
(0.012)\end{array}$ & $\begin{array}{l}-0.020 \\
(0.012)\end{array}$ & $\begin{array}{l}-0.019 \\
(0.012)\end{array}$ \\
\hline Hubei & & & $\begin{array}{l}0.005 \\
(0.010)\end{array}$ & & $\begin{array}{l}0.003 \\
(0.010)\end{array}$ & & $\begin{array}{l}0.004 \\
(0.010)\end{array}$ \\
\hline Age & & & $\begin{array}{l}-0.002^{\star \star \star \star} \\
(0.0002)\end{array}$ & & $\begin{array}{l}-0.002^{\star \star \star \star} \\
(0.0002)\end{array}$ & & $\begin{array}{l}-0.002^{\star \star \star \star} \\
(0.0002)\end{array}$ \\
\hline Sex & & & $\begin{array}{l}0.029^{* \star \star *} \\
(0.004)\end{array}$ & & $\begin{array}{l}0.029^{\star \star \star \star *} \\
(0.004)\end{array}$ & & $\begin{array}{l}0.028^{\star \star \star *} \\
(0.004)\end{array}$ \\
\hline Married & & & $\begin{array}{l}0.013^{*} \\
(0.006)\end{array}$ & & $\begin{array}{l}0.014^{*} \\
(0.006)\end{array}$ & & $\begin{array}{l}0.014^{*} \\
(0.006)\end{array}$ \\
\hline N & 26644 & 26009 & 26009 & 26644 & 26009 & 26009 & 26009 \\
\hline Constant & $\begin{array}{l}0.315^{\star \star \star \star} \\
(0.003)\end{array}$ & $\begin{array}{l}0.331^{\star \star \star \star} \\
(0.005)\end{array}$ & $\begin{array}{l}0.473^{\star \star \star \star} \\
(0.009)\end{array}$ & $\begin{array}{l}0.434^{\star \star \star \star} \\
(0.008)\end{array}$ & $\begin{array}{l}0.475^{\star \star \star \star} \\
(0.010)\end{array}$ & $\begin{array}{l}0.441^{\star \star \star \star} \\
(0.009)\end{array}$ & $\begin{array}{l}0.470^{\star \star \star \star} \\
(0.010)\end{array}$ \\
\hline
\end{tabular}

${ }^{*} \mathrm{P}<0.05,{ }^{* *} \mathrm{p}<0.01,{ }^{* * *} \mathrm{p}<0.005,{ }^{* * * *} \mathrm{p}<0.001$

revealed that older people experienced fewer negative emotions, whereas women and married individuals experienced more negative emotions. These patterns suggest that, across the time periods examined, older people were less emotional but women and married individuals were more emotional (in terms of experiencing emotions of both valences).

\section{DISCUSSION}

Our research findings add to the understanding of how disparities in wealth may be associated with disparities in psychological well-being across the different phases of a disease outbreak. Specifically, our findings suggest that before the onset of a pandemic, having a higher income or owning more properties is associated with a higher level of emotional well-being. A pandemic outbreak can substantially degrade emotional well-being regardless of the types of wealth one possesses. However, the positive effect of having a higher income on emotional well-being can persist during the outbreak. In contrast, owning more properties may not yield the same level of advantage. These differences in the relationship between emotional well-being and income versus property ownership may potentially be attributed to the differences in their convertibility into other resources. The onset of the COVID-19 pandemic compelled people to immediately seek (and even stockpile) many categories of goods, ranging from food and medicine to paper towels and toilet papers, from masks and disinfectants to security cameras and firearms. ${ }^{14}$ Because of its high convertibility, 


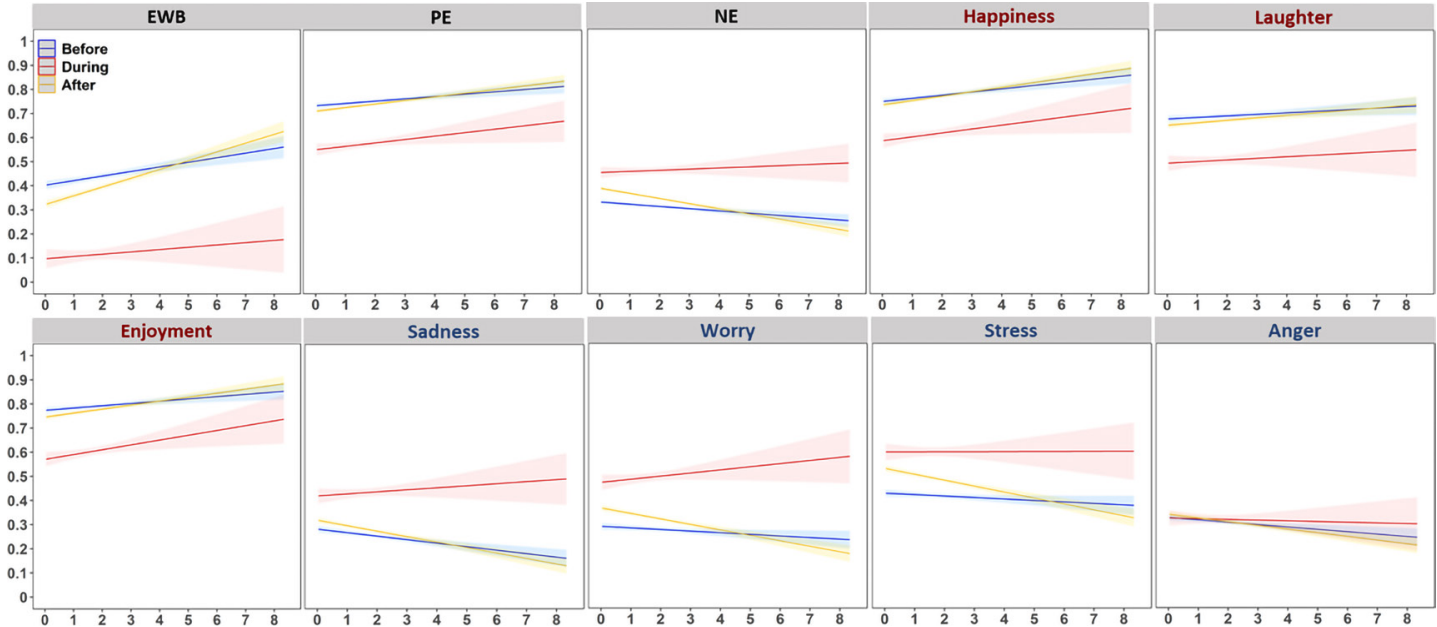

Figure 1 The relationship between income and emotional well-being before, during, vs after the nationwide COVID-19 outbreak. $\mathrm{X}$ axis represents household income (in RMB10 000 increments). Y axis represents emotional well-being. The panels are, respectively, overall emotional well-being index (EWB), positive emotion index (PE), negative emotion index (NE), happiness, smile/laughter, enjoyment, sadness, worry, stress and anger. Blue line represents the period before the nationwide coronavirus outbreak; red line, during the outbreak; yellow line, after the nationwide outbreak. Shaded areas represent the $95 \% \mathrm{Cl}$ for the respective line.

having more 'liquid' wealth such as a higher income can enable individuals to more quickly obtain these resources. This can potentially provide a sense of control, which may help attenuate the detrimental impact of a pandemic on emotional well-being. ${ }^{4}$ In contrast, having more 'illiquid' wealth such as real estate cannot offer the same level of resource convertibility and thus may not help protect against the emotional blow of the pandemic to the same degree.

Our findings also suggest that shortly after the end of a pandemic, having either a higher income or owning more properties can again predict a higher level of emotional well-being. The highest income segment may even experience better emotional well-being after versus before the pandemic. However, the opposite may be true for the lowest income segment. This pattern may potentially be attributed to that people at the highest income levels are able to immediately engage in more happiness-boosting/ stress-reducing activities than before, whereas those at the lowest income levels have to curtail their non-essential, hedonic consumption activities. ${ }^{15}$ Overall, these results add to the literature on how disease outbreaks impact mental health, illustrating the link between disparities in wealth and disparities in psychological well-being across disease outbreak phases. Our findings also inform policies, programmes and interventions aimed at caring for people's emotional well-being, especially that of the most psychologically vulnerable groups, in the age of pandemics.

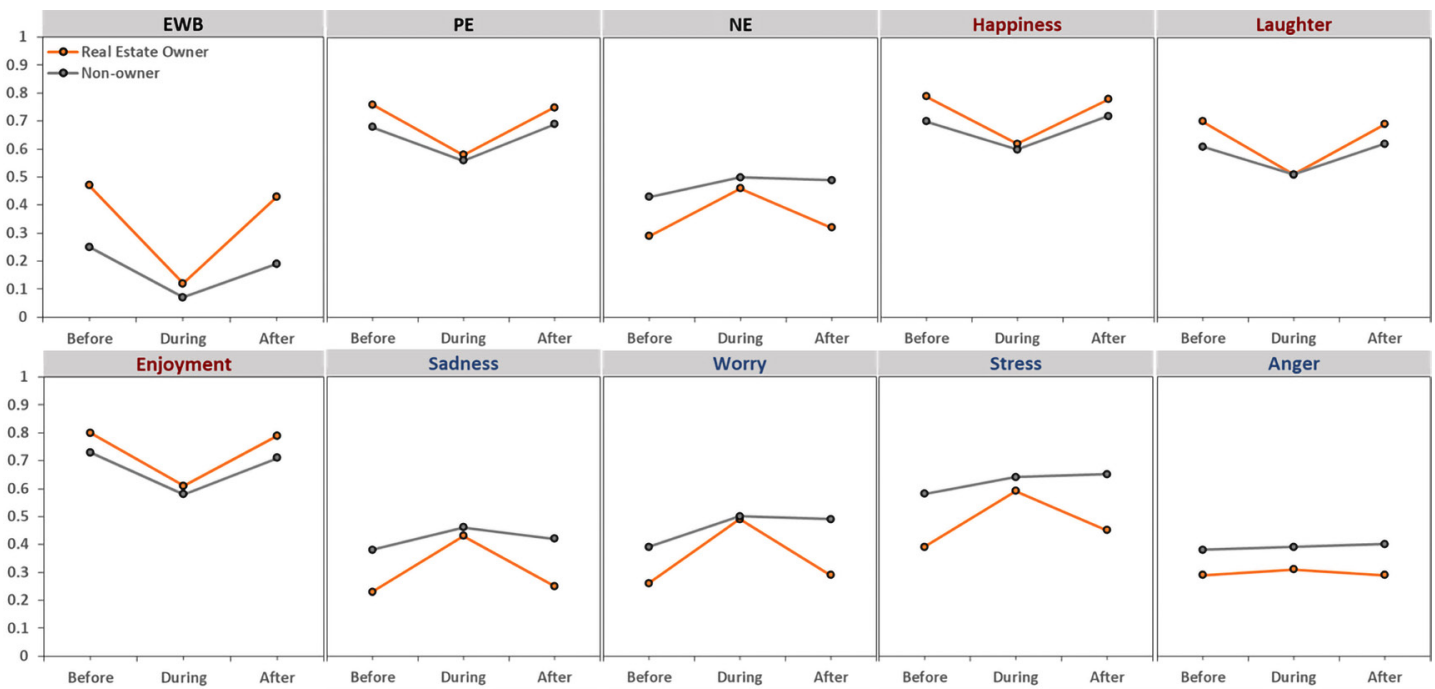

Figure 2 The relationship between real estate ownership and emotional well-being (EWB) before, during, versus after the nationwide COVID-19 outbreak. $X$ axis represents the three time periods: before, during, versus after the nationwide coronavirus outbreak. Y axis represents emotional well-being. Orange line represents real estate owners; grey line, non-owners. NE, negative emotion; PE, positive emotion. 


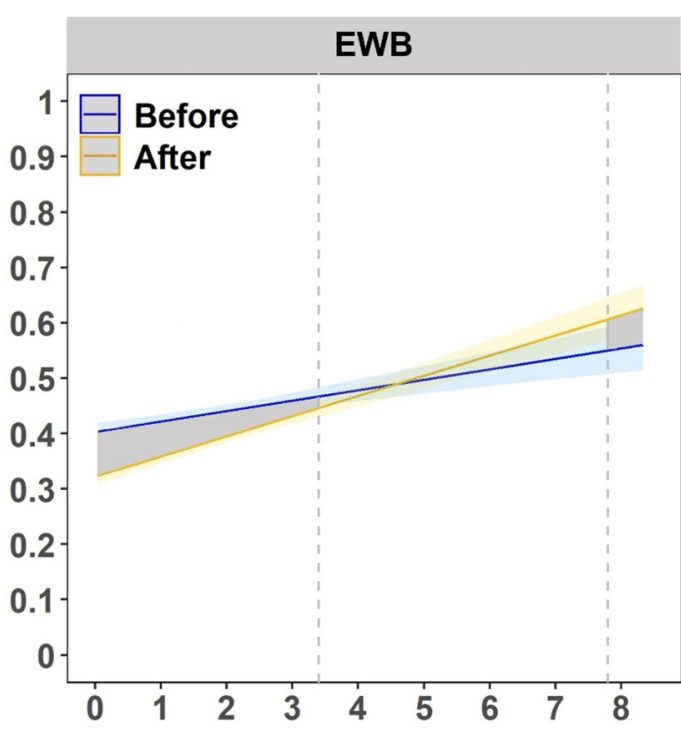

Figure 3 The relationship between income and emotional well-being before vs after the nationwide COVID-19 outbreak. $X$ axis represents household income (in RMB10 000 increments). $Y$ axis represents overall emotional wellbeing (EWB). Blue line represents the period before the nationwide coronavirus outbreak; yellow line, after the nationwide outbreak. Shaded areas represent the $95 \% \mathrm{Cl}$ for the respective line. The grey area represents the JohnsonNeyman regions of significance. The area between the two dashed lines represent the region of non-significance. Specifically, those with an income higher than the dash line on the right, experienced significantly better overall emotional well-being after the outbreak had been contained than prior to the outbreak. In contrast, those with an income lower than the dash line on the left, were significantly worse off after the end of the nationwide outbreak than before the outbreak began.

Finally, our findings suggest several directions for future research. First, our investigation focused on individuals residing in China. As countries may differ in factors such as economic development, culture and pandemic-related policies, the extent to which the findings are generalisable to residents of other countries requires further research. Second, the postoutbreak data collection round was conducted right after the nationwide COVID-19 outbreak had been contained in China and its economy reopened. However, there were sporadic cases occurring. Thus, the longer-term (eg, after the complete eradication of COVID-19) psychological implications of experiencing a nationwide disease outbreak require further research. Third, we found that wealth levels interacted with different pandemic phases to impact psychological wellbeing. Although we controlled for variables (eg, age, location) that correlate with physical health, future research can use more robust approaches (eg, objective measure of one's physical health) to account for the potential influences of physical health on psychological well-being. Moreover, participants' emotional experiences in this cross-sectional investigation were captured using selfreported measures. Future research using longitudinal approaches and behavioural measures may potentially uncover further insights.

Acknowledgements We thank the Data Intelligence and National Development Lab at Peking University for providing the datasets used in this research, and Wanyue Zhang for her research assistance.

Contributors JM obtained the datasets. HY and JM designed the research, analysed the data and wrote the manuscript.

Funding The authors have not declared a specific grant for this research from any funding agency in the public, commercial or not-for-profit sectors.

Competing interests None declared.

Patient and public involvement Patients and/or the public were not involved in the design, or conduct, or reporting, or dissemination plans of this research.

Patient consent for publication Not required.

Ethics approval The data collection in this research received approval from the National School of Development at Peking University.

Provenance and peer review Not commissioned; externally peer reviewed.

Data availability statement Data are available on reasonable request.

Open access This is an open access article distributed in accordance with the Creative Commons Attribution Non Commercial (CC BY-NC 4.0) license, which permits others to distribute, remix, adapt, build upon this work non-commercially, and license their derivative works on different terms, provided the original work is properly cited, appropriate credit is given, any changes made indicated, and the use is non-commercial. See: http://creativecommons.org/licenses/by-nc/4.0/.

ORCID iDs

Haiyang Yang http://orcid.org/0000-0003-3029-5201

Jingjing Ma http://orcid.org/0000-0002-3320-7476

\section{REFERENCES}

1 Jones KE, Patel NG, Levy MA, et al. Global trends in emerging infectious diseases. Nature 2008;451:990-3.

2 Morse SS. Factors in the emergence of infectious diseases. Emerg Infect Dis 1995;1:7-15.

3 Wolfe N. The viral storm: the dawn of a new pandemic age. New York: Macmilla, 2011.

4 Yang $\mathrm{H}$, Ma J. How an epidemic outbreak impacts happiness: factors that worsen (vs. protect) emotional well-being during the coronavirus pandemic. Psychiatry Res 2020;289:113045.

5 Diener E, Biswas-Diener R. Will money increase subjective wellbeing? Soc Indic Res 2002;57:119-69.

6 Kahneman D, Deaton A. High income improves evaluation of life but not emotional well-being. Proc Natl Acad Sci U S A 2010;107:16489-93.

7 Kahneman D, Krueger AB, Schkade D, et al. Would you be happier if you were richer? A focusing illusion. Science 2006;312:1908-10.

8 Ahmed S, Mvalo T, Akech S, et al. Protecting children in low-income and middle-income countries from COVID-19. BMJ Glob Health 2020;5:e002844.

9 Tran PB, Hensing G, Wingfield T, et al. Income security during public health emergencies: the COVID-19 poverty trap in Vietnam. BMJ Glob Health 2020;5:e002504.

10 Ringen S. Direct and indirect measures of poverty. J Soc Policy 1988;17:351-65.

11 Diener E, Wirtz D, Tov W, et al. New well-being measures: short scales to assess flourishing and positive and negative feelings. Soc Indic Res 2010;97:143-56.

12 Dong E, Du H, Gardner L. An interactive web-based dashboard to track COVID-19 in real time. Lancet Infect Dis 2020;20:533-4.

13 Johnson P, Neyman J. Tests of certain linear hypotheses and their application to some educational problems. Statistical Research Memoirs 1936;1:57-93.

14 CNBC. Board games, yoga mats and yeast: what people are buying as they heed coronavirus stay-at-home orders. Available: https:// www.cnbc.com/2020/03/23/what-people-are-buying-during-thecoronavirus-outbreak-and-why.html [Accessed 5 Jun 2020].

15 Peking University. Chinese Consumer Confident Index [CCCl]. Available: https://www.nsd.pku.edu.cn/zsfb/zgxfzxxzs/502572.htm [Accessed 5 Jun 2020]. 